\title{
PENGARUH PENGGUNAAN ASAM LEMAK RANTAI PANJANG DALAM PAKAN TERHADAP PENAMPILAN DAN PROFIL LEMAK DARAH SERTA GAMBARAN OVARIUM AYAM KAMPUNG BETINA
}

\author{
Ning Iriyanti ${ }^{1}$, Tri Yuwanta ${ }^{2}$, Zuprizal ${ }^{2}$ dan Sunarjo Keman ${ }^{2}$
}

\section{INTISARI}

Penelitan ini bertujuan untuk mengetahui pengaruh penggunaan asam lemak rantai panjang asal minyak kelapa sawit dan minyak ikan lemuru pada pakan terhadap penampilan produksi dan profil lipida darah yang meliputi kolesterol, High Density Lipoprotein (HDL), Low Density Lipoprotein (LDL) dan trigliserida darah serta gambaran ovarium ayam kampung. Sebanyak 72 ekor ayam kampung betina umur dua minggu digunakan sebagai temak uji pada 24 unit kandang perlakuan. Perlakuan pakan yang digunakan adalah kombinasi minyak kelapa sawit (MKS) dan minyak ikan lemuru (MIL) yaitu R0 (pakan control, tanpa MKS dan MIL); R1 (pakan dengan 10\% MKS); R2 (pakan dengan 10\% MIL); R3 (pakan dengan 5\% MKS dan 5\% ML). Model dan rancangan penelitian menggunakan metode eksperimen, rancangan acak lengkap dengan enam ulangan dan masing-masing terdiri dari tiga ekor ayam kampung. Variabel yang diukur adalah penampilan ayam terdiri dari pertambahan berat badan, konsumsi pakan, konversi pakan, efisensi pakan, konsumsi lemak, konsumsi energi, kadar kolesterol, HDL, LDL dan trigliserida serum darah pada pengambilan umur 6 dan 22 bulan. Gambaran ovarium diambil dari ayam umur 12 bulan. Hasil penelitian menunjukkan bahwa terjadi perbedaan yang nyata terhadap penampilan ayam kampung betina khususnya terhadap kenaikan berat badan, konsumsi lemak dan energi. Kandungan kolesterol, LDL dan trigliserida sangat nyata ditentukan oleh MKS dam MIL dalam pakan tetapi perlakuan pakan tidak memberikan efek terhadap kadar HDL. Struktur ovarium dan histologis folikel memperlihatkan adanya perbedan karena pengaruh pakan.

(Kata kunci: Asam lemak rantai panjang, Minyak kelapa sawit, Minyak ikan lemuru, Profil Lipid Darah, Ovarium).

\footnotetext{
${ }^{1}$ Fakultas Peternakan Universitas Jenderal Soedirman, Purwokerto.
}

${ }^{2}$ Fakultas Peternakan Universitas Gadjah Mada, Yogyakarta. 


\title{
UTILIZATION OF LONG CHAIN FATTY ACID IN FEMALE NATIVE CHICKEN RATION ON PRODUCTION PERFORMANCE AND BLOOD LIPIDE PROFILE AND OVARIUM PROFILE OF FEMALE NATIVE CHICKEN
}

\begin{abstract}
The aim of this study was to know the effect of the use of long chain fatty acid from kernel palm oil and menhaden oil in feed on cholesterol, High Density Lipoprotein (HDL), Low Density Lipoprotein (LDL) and triglyceride content in native chicken blood and on production performance of kampong native chicken. As much as 72 kampong chickens were used as trial animal on 24 units of pens. The treatment feeds used lipid content which were kernel palm oil (MKS) and Pacific menhaden oil (MIL) i.e. R0 (control, without MKS and MIL); R1 (feed with 10\% MKS); R2 (feed with $10 \%$ MIL); R3 (feed with 5\% MKS and 5\% ML). The model and design of the research used experimental method of Completely Randomized Design with six replications which consisted of three birds each. Variable bring measured were cholesterol, HDL, LDL and triglyceride in blood serum which were carried out at 6 months and 24 months of ages. The result of this study indicated that there were significant differences on average gain weight, lipid consumption and energy consumption of experimental animals; and blood cholesterol, LDL and triglyceride contents were significantly influenced by dietary treatment. There were an indication of different profile on ovarian structure and follicle histology.
\end{abstract}

(Key words: Long chain fatty acid, Kernel palm oil, Pacific menhaden oil, Blood Lipid Profile, Ovarian).

\section{Pendahuluan}

Kendala yang dihadapi pada pemeliharaan ayam lokal ada tiga yaitu sumber daya peternak, ternaknya itu sendiri serta kebijakan pemerintah (Yuwanta, et al., 2002). Dari berbagai kendala tersebut maka diperlukan suatu usaha agar ayam lokal ini mampu mengimbangi populasi ayam ras, usaha tersebut antara lain peningkatkan populasi, produksi, produktivitas dan effisiensi ditunjang oleh peningkatan kualitas serta reorientasi dari budidaya centris ke arah agribisnis (Yodohusodo, 2003). Pada dasarnya pemeliharaan ayam lokal dapat memberikan hasil yang maksimal apabila dipelihara secara intensif, penyusunan dan pemberian ransum yang berkualitas cukup untuk pertumbuhan dan produksi serta program vaksinasi dan pencegahan penyakit yang terkontrol. Selain genetik, peningkatan produksi dan reproduksi ayam lokal sangatlah bergantung dari pakan yang diberikan. Asam lemak essensial merupakan salah satu nutrien yang penting untuk ayam karena asam lemak ini berhubungan dengan integritas pada struktur membran mitokondria dan terdapat dalam konsentrasi tinggi pada organ-organ reproduksi, pada fosfolipid dan juga sebagai prekursor pembentukan kolesterol (Tranggono, 2001). Peningkatan produksi dan reproduksi ayam lokal sangatlah bergantung dari pakan yang diberikan terutama asam lemak essensial, asam lemak berikatan rangkap tinggi bertanggung jawab terhadap permeabilitas dan aktivitas membran untuk mengikat enzim dan mengatur proliferasi sel, komponen asam empedu, dan penyusun hormon steroid termasuk didalamnya hormon reproduksi.

Sekitar $80 \%$ dari total kolesterol tubuh adalah dalam bentuk LDL dan $90 \%$ kolesterol dalam bentuk HDL. Biosintesis kolesterol terutama terjadi di dalam jaringan hati, $33 \%$ berasal dari makanan dan $67 \%$ disintesis dalam tubuh (Rettersol et al., 1998). LDL merupakan lipoprotein terkecil, paling banyak mengandung kolesterol, dan merupakan pengirim kolesterol utama dalam darah. Sel-sel tubuh memerlukan kolesterol untuk tumbuh dan berkembang, dan sel-sel ini memperoleh kolesterol dari LDL. Kolesterol yang dapat diserap mempunyai batas tertentu, untuk itu sel mengurangi pembentukan 
reseptor LDL, sehingga kolesterol dalam darah naik, dan terjadi penumpukan kolesterol pada dinding arteri. Sementara itu HDL merupakan lipoprotein dengan kandungan protein yang paling banyak, ketika melalui darah $\mathrm{HDL}$ mengumpulkan kelebihan kolesterol dari jaringan tubuh dan mengembalikan ke hati, serta mengeluarkannya bersama-sama dengan empedu. Kolesterol dapat diserap 20-50\%, sedangkan sekitar $80 \%$ dapat diserap tanpa melalui system pencernaan.

Absorbsi kolesterol yang maksimal terjadi di usus halus bagian tengah dan ujung ileum dimana micelle mengandung jumlah asam lemak dan monogliserida yang optimal. Pada saat terjadinya absorbsi kolesterol dan lemak dalam usus halus, micelle akan pecah. Sesudah absobsi ke dalam sel mukosa kolesterol dibentuk kembali bersama-sama dengan trigliserida, fosfolipid, apoprotein dan membentuk kilomikron dan berasama-sama dengan Very Low Density Lipoprotein (VLDL) untuk diserap ke dalam limfa sebanyak $80-90 \%$ yang diesterkan dengan asam lemak rantai panjang. VLDL yang dibentuk dalam hati akan mengangkut kolesterol ke dalam plasma.

Kolesterol merupakan komponen penting pada mebram sel dan lipoprotein plasma juga merupakan prokursor steroid yang secara biologis sangat penting seperti garam empedu dan beberapa hormon steroid. Kolesterol yang lebih dari $300 \mathrm{mg} / 100 \mathrm{ml}$ dapat berakibat negatif seperti indikasi adanya penyakit jantung. Biosintesis kolesterol, HDL, LDL pada plasma darah ayam dapat diatur dengan melalui manipulasi pakan menggunakan perbedaan asam lemak dalam ransum. Berdasarkan pemikiran tersebut maka dilakukan penelitian dengan bertujuan untuk mengetahui pengaruh penggunaan asam lemak rantai panjang asal minyak kelapa sawit dan minyak ikan lemuru pada pakan terhadap penampilan produksi dan profil lipida darah yang meliputi kolesterol, HDL, LDL dan trigliserida darah ayam kampung.

\section{Materi dan Metode}

Penelitian dilakukan pada bulan April sampai Oktober 2004 di Sub Stasiun Percobaan
Fakultas Peternakan Universitas Jenderal Soedirman dan di Laboratorium Makanan Ternak, Jurusan Nutrisi dan Makanan Ternak, Fakuitas Peternakan UGM Jogjakarta.

Penelitian ini menggunakan 72 ekor ayam kampung betina yang dipelihara dari umur 22 minggu sampai umur 96 minggu. Ayam ditempatkan pada 48 unit kandang baterai dengan ukuran $90 \times 90 \times 90 \mathrm{~cm}$. Pakan perlakuan mengandung minyak ikan lemuru dan minyak kelapa sawit dengan perbandingan: 0:0 (R0); 0:10 (R1); 10:0 (R2) dan 5:5 (R3) \%/kg pakan, yang ditambahkan pada bahan pakan basal dari jagung, dedak, tepung ikan, bungkil kedele, Llisin, dan DL-metionin, serta mineral top mix. Setiap perlakuan diulangi enam kali dengan menggunakan tiga ekor/ulangan. Kandungan protein kasar pakan $17 \%$ dengan Energi Metabolis $2900 \mathrm{kcal} / \mathrm{kg}$ (Tabel 1). Darah diambil pada daerah vena sayap pada pada ayam betina umur 6 bulan dan 22 bulan. Darah diambil dengan "disposable plastic syringes" sebanyak 1-2 ml kemudian dicentrifuge $5000 \mathrm{rpm}$ selama 10 menit kemudian supernatan diambil untuk dianalisis dengan spektofotometer.

Variabel yang diamati berupa penampilan ayam yang meliputi konsumsi pakan harian (g/ekor/hari), konsumsi energi, konsumsi lemak, kenaikan berat badan evolusi berat badan setiap 4 minggu dan konversi pakan. Profil lemak darah yang diamati adalah kadar kolesterol, HDL, LDL, dan Trigliserida, trigliserol dan ester klesterol yang ditentukan dengan mencocokkan absorbansinya dengan kurva standar menggunakan metode Lieberman dan Burchard. (Tranggono dan Setiaji, 1989).

\section{Hasil dan Pembahasan}

Hasil penelitian terhadap penampilan ayam kampung betina seperti terlihat pada Tabel 2 . Hasil analisis variansi menunjukkan bahwa perlakuan berpengaruh nyata terhadap performan produksi terutama terhadap kenaikan berat badan dan konsumsi lemak. Perlakuan R3 menurunkan angka konversi pakan dan meningkatkan pertumbuhan, hal ini disebabkan karena pada pakan R3 (5\% minyak kelapa dan $5 \%$ minyak kelapa sawit merupakan kombinasi asam-asam lemak omega- 3 , omega- 6 dan 
Tabel 1. Komposisi nutrien ransum ayam kampung betina (Nutrient composition of native chicken diet)

\begin{tabular}{lcccc}
\hline \multicolumn{1}{c}{ Bahan pakan (\%) (Ingredient, \%) } & $\mathrm{R}-0$ & $\mathrm{R}-1$ & $\mathrm{R}-2$ & $\mathrm{R}-3$ \\
\hline Minyak Ikan Lemuru (MIL) (Manhaden Oil) & 0 & 0 & 10 & 5 \\
Minyak Kelapa Sawit (MKS) (Coconut Oil) & 0 & 10 & 0 & 5 \\
Jagung giling (Corn gluten meal) & 62,00 & 27,00 & 27,00 & 27,00 \\
Dedak padi (Rice brand) & 7,00 & 31,00 & 31,00 & 31,00 \\
Bungkil kedele (Soybean meal) & 13,00 & 15,00 & 15,00 & 15,00 \\
Tepung ikan (Fish meal) & 7,00 & 6,00 & 6,00 & 6,00 \\
Tepung batu kapur (CaCO ${ }_{3}$ ) & 7,00 & 7,00 & 7,00 & 7,00 \\
Garam (Salt) & 1,00 & 1,00 & 1,00 & 1,00 \\
DL-Metionin (DL-Methionine) & 0,75 & 0,75 & 0,75 & 0,75 \\
L-Lisin (L-Lysine) & 0,75 & 0,75 & 0,75 & 0,75 \\
Topmix * (Mineral Mix) & 1,50 & 1,50 & 1,50 & 1,50 \\
\hline Jumlah (Total) & 100 & 100 & 100 & 100 \\
\hline Komposisi kimia pakan (Nutrient composition): & & & & \\
Protein kasar (Crude protein) (\%) & 15,21 & 15,31 & 15,07 & 15,44 \\
Energi metabolis (Metabolizable Energy (kcal/kg) & $2.900,00$ & $3.000,00$ & $3.000,00$ & $3.000,00$ \\
Lemak (Lipid) (\%) & 3,85 & 4,97 & 4,97 & 4,97 \\
Serat Kasar (Crude Fiber) (\%) & 2,45 & 2,99 & 2,99 & 2,99 \\
Ca (Calcium) (\%) & 3,00 & 3,00 & 3,00 & 3,00 \\
P tersedia (Disponible Phoshopus) (\%) & 0,55 & 0,72 & 0,72 & 0,72 \\
Lisin (Lysin) (\%) & 1,03 & 1,01 & 1,01 & 1,01 \\
Metionin (Methionin) (\%) & 1,57 & 1,60 & 1,60 & 1,60 \\
Total n=3 & 0,77 & 13,22 & 14,07 & 14,92 \\
Total n=6 & 1,20 & 13,21 & 12,07 & 10,93 \\
Total n=9 & 49,14 & 21,70 & 19,16 & 16,62 \\
\hline
\end{tabular}

Tabel 2. Pengaruh pakan perlakuan terhadap kinerja produksi ayam kampung (Effect of ration treatment on performance of kampung native chickens)

\begin{tabular}{|c|c|c|c|c|}
\hline Variabel (Variable) & R0 & R1 & R2 & $\mathrm{R} 3$ \\
\hline Peningkatan Berat Badan ( $\mathrm{g} / \mathrm{ek} / \mathrm{hr})^{\circ}$ (Gain weight, g/bird/day) & $11,16^{\mathrm{a}}$ & $11,84^{\mathrm{a}}$ & $15,40^{6}$ & $14,13^{\text {ab }}$ \\
\hline kan $(\mathrm{g} / \mathrm{ek} / \mathrm{hr})^{\mathrm{ns}}$ (Feed consumption, g/bird/day) & 61,80 & 62,83 & 65,31 & 64,28 \\
\hline (Feed Conversion) & 5,24 & 5,17 & 4,84 & 4,64 \\
\hline Konsumsi lemak (g/ek/hr) ${ }^{* *}$ (Lipid consumption, g/bird/day) & $3,19^{\mathrm{a}}$ & $3,18^{\mathrm{a}}$ & $3,39^{\mathrm{b}}$ & $3,16^{a}$ \\
\hline $\begin{array}{l}\text { Konsumsi energi }(\mathrm{cal} / \mathrm{ek} / \mathrm{hr})^{\mathrm{ns}} \text { (Energy consumption, } \\
\mathrm{cal} / \text { bird/day) }\end{array}$ & $221,18^{\mathrm{a}}$ & $219,52^{3}$ & $233,17^{b}$ & $216,98^{\mathrm{a}}$ \\
\hline
\end{tabular}

ns : Tidak berbedanyata (Not significant)

a,b : Superskrip yang berbeda pada kolom yang sama menunjukkan perbedaan nyata $(\mathrm{P}<0,01)$ (Different superscript at the same coloumn indicating significant differences $(P<0.01)$.

omega-9 yang paling seimbang. Komponen asam lemak tidak jenuh yang utama adalah asam lemak oleat (omega-9) yang mempunyai I ikatan rangkap; linoleat (omega-6) dengan 2 ikatan rangkap dan linolenat (omega-3) dengan 3 ikatan rangkap, posisi ikatan rangkap dimulai dari ujung metil. Asam lemak tidak jenuh bagi ternak merupakan asam lemak essensial, sehingga kebutuhannya harus dipenuhi dalam pakan dalam jumlah yang mencukupi (Linder, 1985).

Penambahan minyak lemuru dan minyak sawit dalam ransum menunjukkan peningkatan konsumsi pakan daripada ransum kontrol (R-0), hal ini disebabkan oleh pengaruh minyak yang 
Tabel 3. Kandungan kolesterol, HDL, LDL, dan Trigliserida pada ayam kampung betina (Cholesterol, HDL, LDL and triglyseride concentration of kampung female chicken)

\begin{tabular}{|c|c|c|c|c|}
\hline \multirow[t]{2}{*}{ Pengamatan Variabel (Variable items) } & \multicolumn{4}{|c|}{ Perlakuan (Treatment) } \\
\hline & R0 & R1 & R2 & R3 \\
\hline Kolesterol (Cholesterol) (mg/dl)** & $100,00^{\mathrm{a}}$ & $104,66^{26}$ & $108,30^{6}$ & $95,81^{a}$ \\
\hline $\mathrm{HDL}(\mathrm{mg} / \mathrm{dl})^{\mathrm{ns}}$ & 30,34 & 30,34 & 28,86 & 31,82 \\
\hline Trigliserida (Triglyceride) $(\mathrm{mg} / \mathrm{dl}) * *$ & $66,66^{b}$ & $83,33^{\mathrm{b}}$ & $33,33^{a}$ & $33,31^{\mathrm{a}}$ \\
\hline $\mathrm{LDL}(\mathrm{mg} / \mathrm{dl})^{* *}$ & $39,36^{\mathrm{a}}$ & $36,443^{a}$ & $64,32^{\mathrm{c}}$ & $48,90^{\mathrm{b}}$ \\
\hline
\end{tabular}

ab.e Superskrip yang berbeda pada kolom yang sama menunjukkan perbedaan nyata $(\mathrm{P}<0,01)$ (Different superscript at the same coloumn indicating significant differences $(P<0.01)$.

dapat meningkatkan physical characteristic, emulsi lemak, rate of passage pakan dan extra calory effect di saluran pencernaan.

Konsumsi pakan dipengaruhi oleh perbedaan komposisi asam lemak, selanjutnya dijelaskan bahwa ayam akan makan lebih banyak bila diberi asam palmitat dan stearat dibanding ransum mengandung oleat dan linoleat. Kombinasi minyak lemuru dan sawit 4\% (R-3) menunjukkan peningkatan konsumsi, hal ini karena imbangan ratio konsumsi PUFA dan MUFA yang seimbang sehinga ransum lebih palatable. Penurunan konsumsi pada R-0 (ransum tanpa miyak) karena kandungan lemak dalam ransum rendah $(3,6 \%)$ sehingga menyebabkan ransum kurang palatable dan juga konsumsi asam-asam lemak serta ratio MUFA dan PUFA rendah. Hasil serupa ditemui pada pengunaan $5 \%$ minyak lemuru dalam ransum puyuh (Saerang, 1997) dan $8 \%$ minyak lemuru pada ransum ayam petelur (Sulistiawati, 1998) memberikan kecenderungan produksi yang lebih baik dari pada ransum yang mengandung miyak sawit atau nabati maupun kontrol. Peningkatan produksi terhadap konsumsi pakan berakibat turunnya angka konversi pakan, karena konversi pakan memiliki hubungan yang erat dengan konsumsi pakan dan egg mass. Perlakuan berpengaruh nyata terhadap konsumsi lemak hal ini disebabkan karena lemak dalam ransum merupakan sumber energi yang lebih efektif dibanding karbohidrat dan protein, dengan metabolizable energy (ME) sekitar $7.700 \mathrm{kcal} / \mathrm{kg}$ (Patrick dan Schaible, 1980). Nilai energi minyak tergantung pada kandungan asam lemak penyusunnya, yaitu panjang dan pendeknya rantai karbon penyusun asam lemak dan ada tidaknya ikatan rangkap.

Hasil penelitian tentang kandungan kolesterol, HDL, LDL dan trigliserida darah pada ayam betina tersaji pada Tabel 3. Hasil analisis variansi kandungan asam lemak pada ayam betina menunjukkan perbedaan yang sangat nyata $(\mathrm{P}<0,001)$ terhadap kandungan kolesterol, trigliserida dan LDL. Menurut Van Elswyk (1997), minyak ikan dapat menurunkan kandungan VLDL kolesterol dan trigliserida dalam darah ayam jantan. Manfaat lainnya adalah bahwa asam lemak omega-3 akan dimetabolisme menghasilkan aikosanoid seperti prostaglandin yang berfungsi mengurangi terjadinya peradangan, mencegah agregasi platelet dan mengurangi resiko penyakit jantung.

Asam lemak omega-3 juga berpengaruh terhadap penurunan trigliserida dan VLDL plasma, menurunkan gejala hiperlipaemia, meningkatkan proses pembekuan darah, menurunkan tekanan darah systolic dan diastolik dan menurunkan artherisclerosis, serta menurunkan resiko terkena penyakit jantung (Leskanich dan Noble, 1997). Whitehead (1984) menyatakan bahwa komposisi asam lemak karkas dipengaruhi oleh macam dan jumlah lemak yang ditambahkan dalam ransum. Penambahan minyak ikan lemuru akan meningkatkan kandungan asam lemak $\mathrm{n}-3$ (linolenat, eikosapentanoat dan dekosaheksaenoat) terutama EPA dan DHA dan belum berpengaruh terhdap kandungan asam lemak n-6 (linoleat dan arachidonat). Kadar lemak daging sangat bervariasi antara 5,97 $13,76 \%$, SAFA $=68,87-81,9 \%$, MUFA $=15,41-$ $23,88 \%$, PUFA $=0,02-4,04 \%$. 

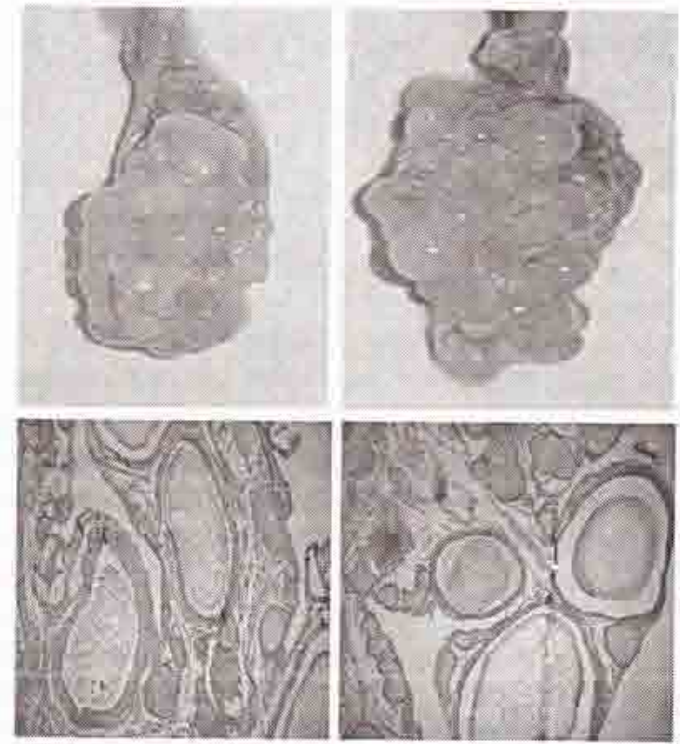

R-0

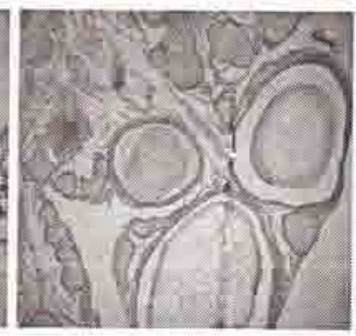

R-1
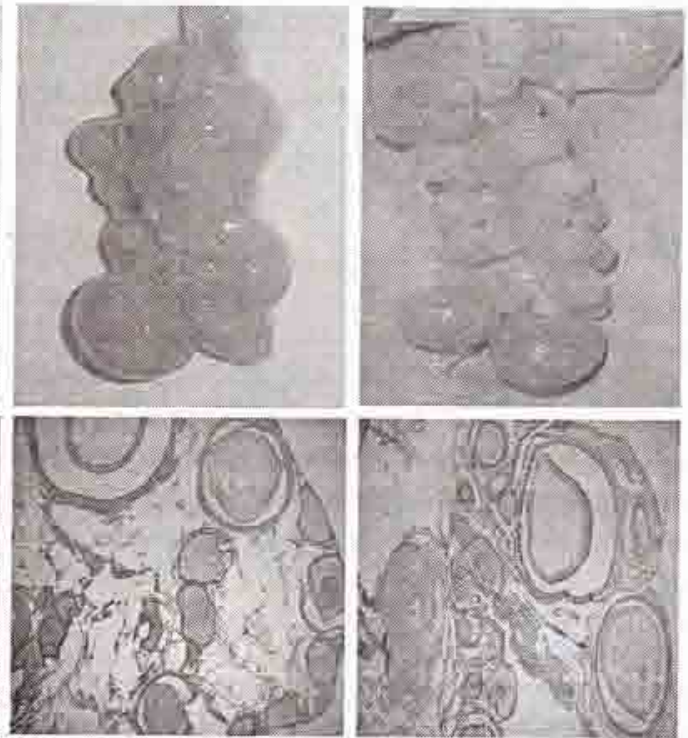

R-3

Gambar 1. Profil ovarium dan gambaran histologis folikel ayam kampung umur 12 bulan (Ovarium profile and follicle histologys of kampung chicken age of 12 months).

Hasil analisis variansi menunjukkan bahwa pengaruh pemberian minyak kelapa sawit dan minyak ikan lemuru berpengaruh nyata $(\mathrm{P}<0,05)$ terhadap kandungan kolesterol, LDL dan trigliserida tetapi berpengaruh tidak nyata terhadap kandungan HDL serum darah ayam kampung jantan. Van Elswyk (1997) menyatakan bahwa minyak ikan dapat menurunkan kandungan very low density lipoprotein (VLDL) kolesterol dan trigliserida dalam darah ayam jantan. Manfaat lainnya adalah bahwa asam lemak omega-3 akan dimetabolisme untuk menghasilkan aikosanoid seperti prostaglandin yang berfungsi mengurangi terjadinya peradangan, mencegah agregasi platelet dan mengurangi resiko penyakit jantung (Marshall $e t$ al., 1994). Kombinasi antara pemberian minyak ikan lemuru $5 \%$ dan minyak kelapa sawit $5 \%$ memberikan hasil yang terbaik dibanding perlakuan yang lain. Hal ini juga terlihat pada ovarium yang dihasilkan pada perlakuan maupun gambaran histologis folikel dari setiap perlakuan (Gambar 1). Perbandingan yang optimum dari omega-3 dan omega- 6 sangat penting diupayakan,karena dalam menjalankan fungsi biologis omega- -3 berkompetisi dengan omega -6 . Untuk mengatasi kondisi yang istimewa maka bahan pangan yang berkadar omega- 3 tinggi secara relatif jumlah omega-6 harus diperhatikan supaya manfaat positif bisa diharapkan (Herold and Kinsella, 1986).

Asam lemak omega-3 mempunyai pengaruh yang menciri khusus berbeda dengan asam lemak yang lain (Latta, 1990). Asam lemak jenis ini, seperti asam eikosapentaenoat (C 20:5) dan asam dokosaheksaenoat (C 22:6) banyak terdapat dalam banyak lemak ikan. Adapun yang termasuk asam lemak omega-6 adalah asam lenoleat (C 18:2n-6) dan (C 20:4n-6) atau asam arachidonat (Kinsella, 1987). Eiokasapentaenoat (EPA) dan dokosaheksaenoat (DHA) berinteraksi dengan baik dalam tubuh bila arachidonat $(2: 4 \mathrm{n}-6)$ atau omega-6 dalam perbandingan yang sesuai (Kinsella, 1988). Di Australia ratio omega- 6 dan omega- 3 yang tidak serasi rata-rata ratio omega- 6 terhadap omega- 3 
sekitar 23-30:1, padahal yang ideal adalah apabila dapat mendekati ratio $5: 1$ (Farrel, 1996). Campuran asam lemak jenuh dan tak jenuh memberikan hasil yang lebih baik, hal ini berkaitan dengan sinergisme pada pembentukan misel sehingga lebih mudah diabsorbsi (Leeson dan Atteh, 1995).

Kolesterol yang sampai ke dinding usus berasal dari tiga sumber yaitu makanan, empedu dan sekresi usus maupun sel. Semua kolesterol dalam usus dalam bentuk bebas yaitu tidak teresteririfikasi. Kolesterol yang teresterifikasi dalam pakan secara cepat akan dihidrolisis dalam usus menjadi kolesterol bebas dan asam lemak bebas oleh kolesterol esterase, pancreas dan sekresi usus halus. Untuk dapat diabsorbsi kolesterol harus dilarutkan dahulu yaitu dengan membentuk micelle campuran yang mengandung kolesterol yang tidak teresterifikasi, asam lemak, monogliserida, fosfolipid dan asam empedu. Tingkat absorbsi dipengaruhi oleh bentuk, untuk bentuk kristal tingkat absorbsinya lebih rendah dibanding bentuk alami atau yang terlarut dalam lemak. Meningkatnya jumlah lemak pakan ( $98 \%$ trigliserida) menyebabkan perluasan dari micelle yang mengakibatkan lebih banyak kolesterol yang dapat dilarutkan dan diabsorbsi. Absorbsi kolesterol yang maksimal terjadi di usus halus bagian tengah dan ujung ileum dimana micelle mengandung jumlah asam lemak dan monogliserida yang optimal. Pada saat terjadinya absorbsi kolesterol dan lemak dalam usus halus, micelle akan pecah. Sesudah absobsi kedalam sel mukosa kolesterol dibentuk kembali bersamasama dengan trigliserida, fosfolipid, apoprotein dan membentuk kilomikron dan berasamasama dengan VLDL (Very Low Density Lipoprotein) untuk diserap kedalam limfa sebanyak $80-90 \%$ yang diesterkan dengan asam lemak rantai panjang. VLDL yang dibentuk dalam hati akan mengangkut kolesterol ke dalam plasma. Kolesterol dalam darah juga dipengaruhi oleh keturunan, umur, dan serat kasar, serta perbedaan jenis kandungan asam lemak dalam pakan yang dikonsumsi (Harimurti, 1995). Hasil sejumlah penelitian menunjukkan bahwa penambahan minyak ikan mempunyai pengaruh yang jelas dalam proses ini, yang berpengaruh pada perubahan komposisi lipoprotein darah, tingkat responsinitas platelet, dan darah serta parameter sirkulasi. Hasil penelitian ini sedikit berbeda dari hasil penelitian Zuprizal et al., 2002 bahwa kandungan kolesterol darah berkisar antara 86.95 sampai $539.13 \mathrm{mg} / \mathrm{dl}$, begitu juga dengan kandungan trigliserida dan HDL darah. Hasil ini masih dibawah kisaran standar yaitu $148 \mathrm{mg} / \mathrm{dl}$ (Mitruka dan Rawnsley, 1981).

\section{Kesimpulan}

Kesimpulan dari penelitian ini adalah pemberian minyak kelapa sawit dan minyak ikan lemuru dengan imbangan yang cukup yaitu $5 \%$ : $5 \%$ pada perlakuan R3 menunjukkan angka pertambahan bobot badan dan konversi pakan yang paling tinggi dibanding kontrol, sehingga imbangan ini dapat digunakan dalam ransum ayam kampung betina tanpa memberikan efek negatif terhadap penampilan maupun kandungan kolesterol, HDL, LDL dan trigliserida darah ayam kampung betina. Ovarium dan histologi folikel memberikan gambaran yang berbeda akibatperlakuan.

\section{Ucapan terima kasih}

Ucapan terima kasih disampaikan kepada Proyek Hibah Bersaing XII/I. Tahun 2004 dengan nomor kontrak : 018/P4PT/ DPPM/PHB XII/III/2004 tanggal 1 Maret 2004.

\section{Daftar Pustaka}

Farrel, D. J. 1996. The heart smart egg: Why it is good for you? Makalah pada Seminar International WPSA di Universitas Diponegoro Semarang. September 1996.

Harimurti, S. 1995. Upaya Menurunkan Kadar Kolesterol Telur dengan Suplementasi Vitamin C pada ransum Petelur Berenergi Tinggi, Buletin Peternakan Vol. 19, Desember 1995, Fakultas Peternakan UGM, Yogyakarta.

Herold, P. and J. E. Kinsella, 1986. Fish Oil Consumption and Decreased Risk of Cardiovascular Disease : A Comparison of Fundings from Animal and Human Feeding Trials. Amer J. Clin. Nutz. 43:566. Kinsella, J. E. 1987. Effects of Poly Unsaturoted 
Fatty Acids on Parameters related to Cardiovascular Disease. Am. J. Cardool. 60:236.

Kinsella, J. E. 1988. Fish and Seafoods: Nutritional Implications and Quality Issues. J. Food Technology, May 1988. p.: 146-150.

Latta, S. 1990. Netherland Study Puts Trans in Spotlight Again. INFORM, 1:875 dalam Adnan, M. 1995.

Leeson, S. and J. O. Atteh. 1995. Utilization of fats and fatty acids by turkey poults. Poult. Sci., 74:2003-2010.

Leskanich, C. O. and R. C. Noble. 1997. Manipulation of the $n-3$ polyunsaturated fatty acid composition of avian eggs and meat. World's Poultry Journal 53:155-183.

Linder, M. C. 1985. Biokimia Nutrisi dan Metabolisme UI Press, Jakarta.

Marshall, A. C., K.S. Kubena, K.R. Hinton, P.S. Hargis and M.E. Van Elswyk. 1994. The n3 fatty acids enriched table eggs: a survey of consumer acceptability. Poult. Sci., 73:1334-1340.

Mitruka, B. M. and H. M. Rawnsley. 1981. Clinical Biochemcal and Hematological Reference Values in Normal Experimental Animals and Normal Humans. Second Ed. Year Book Medical Publishers,Inc. Chicago.

Patrick, H. and P. J. Schaible. 1980. Poultry feed and Nutrition. The 2 nd Ed. Chapman and Hall, New York, London.

Rettersol, K. T., B. ugen, B. Woldseth and B. O. Christopherson. 1998. A comparative study of the metabolism of n-9, n-6 and n-3 fatty acids in testicular cells from immature rat. Biochim. Biophys. Acta. 1392:59-72.

Saerang, J. L. P. 1997. Pengaruh minyak nabati dan hewani dalam ransum puyuh petelur terhadap performan, daya tetas, kadar kolesterol telur dan plasma darah. Tesis Program Pascasarjana UGM, Yogyakarta.

Sulistiawati, D. 1998. Pengaruh penggunaan ikan lemuru dan minyak kelapa sawit dalam ransum terhadap kinerja ayam dan kandungan asam lemak omega-3 dalam telur. Tesis, Program Pasca-sarjana UGM, Yogyakarta.

Tranggono dan B. Setiaji. 1989. Petunjuk Laboratorium Biokimia Pangan. PAU Pangan dan Gizi UGM, Yogyakarta.

Tranggono. 2001. Lipid dalam Perspektif Ilmu dan teknologi Pangan. Pidato Pengukuhan Guru Besar Fakultas Teknologi Pertanian UGM.

Van Elswyk, M. E. 1997. Nutritional and Physiological Effects of Flax Seed in Diets for Laying Fowl. World's Poult. Sci. J., 53:253-264.

Whitehead, C. C. 1984. Essential fatty acids in poultry nutrition. In: J. Wiseman (Ed.). Fats in Animal Nutrition. Butterworths, Sidney.

Yodohusodo, S. 2003. Agribisnis Berbasis Peternakan Menghadapi Era Perda-gangan Bebas, Seminar dalam rangka Dies Natalis ke-37 Fakultas Peternakan Universitas Jenderal Soedirman, Purwokerto.

Yuwanta, T., Nasroedin, Zuprizal, Wihandpyo and A.Wibowo. 2002. The Role of Native Chicken in Indonesia Rural. Proc. The 3 rd ISTAP 14-16 October, Yogyakarta, Indonesia.

Zuprizal, Cuk Tri Noviandi, Indratiningsih dan Sri Harimurti. 2002. Studi transfer omegz3 yang berasal dari limbah industri pengolahan ikan terhadap komposisi kimia telur berbagai jenis unggas. Laporan Penelitian Hibah Bersaing (HB IX), Tahun 2001-2002. Lemlit-UGM, Nov. 2002. 